\title{
PHYSICAL PROPERTIES OF 110 MA OCEANIC CRUST AT SITE OSN-1: IMPLICATIONS FOR EMPLACEMENT OF A BOREHOLE SEISMOMETER
}

\author{
David Goldberg \\ Lamont-Doherty Borehole Research Group \\ Daniel Moos \\ Stanford University, Department of Geophysics
}

\begin{abstract}
An extensive suite of downhole geophysical logs was acquired through a $70 \mathrm{~m}$ thick section of basalt drilled by the Ocean Drilling Program (ODP) into $110 \mathrm{Ma}$ oceanic crust $225 \mathrm{~km} \mathrm{SW}$ of Hawaii. These data include standard sonic, electrical, and nuclear logs, as well as electrical and acoustic images of the wellbore, and enable a vertically continuous characterization of the physical properties of shallow, old oceanic crust. Fracture porosity and alteration increase with depth in this hole, and considered together with results obtained elsewhere in both young and old ( 5 to $110 \mathrm{Ma}$ ) crust, suggest that physical properties gradients in the uppermost few hundred meters of oceanic basement are controlled by crustal morphology and alteration and are ubiquitously variable. As this hole was drilled primarily for pilot experiments at the first site of the Ocean Seismic Network, evaluation of the log data demonstrates the importance of careful in-situ data collection in order to emplace a broadband monitoring device below the seafloor for long-term seismic measurements.
\end{abstract}

\section{Introduction}

Ocean Drilling Program (ODP) Hole 843B was drilled 70 meters into the ocean crust on the outer flank of the uniform and thinly sedimented ( $244 \mathrm{~m}$ ) Hawaiian Arch about $225 \mathrm{~km}$ southwest of Oahu [Fig. 1, after Dziewonski, Wilkens, et al., 1992]. The site is located on about $110 \mathrm{Ma}$ oceanic crust, dated by K-Ar techniques [G. Waggoner, pers. comm.], which consists primarily of basalt pillows and sheet lava flows [Larson and Chase, 1972]. The velocity structure of the ocean crust near the Hawaiian Islands, derived from wide-aperture seismic data, has been described in detail by Watts and ten Brink [1989]. The crust thins from $17 \mathrm{~km}$ beneath the Hawaiian islands to 6-7 $\mathrm{km}$ beneath the flexural arch, and the average seismic velocity in the uppermost crust is lower (about $4.2 \mathrm{~km} / \mathrm{s}$ ) beneath the arch than it is closer to the islands $(5.1 \mathrm{~km} / \mathrm{s})$.

An extensive suite of downhole measurements, including, elastic-wave velocity, electrical resistivity, geochemistry, electrical and acoustic wellbore imaging, temperature, and borehole shape was collected at ODP Site 843. These measurements allow continuous, in-situ evaluation of the physical properties of the formation surrounding the borehole [e.g. Matthews et al., 1990]. Our overall objectives in this study are to determine from the log data: (1) the nature and variability of physical properties gradients at this crustal site, (2) their comparison to other oceanic crustal sites, and (3) the suitability of the hole itself as a potential Ocean Seismic Network (OSN) site.

\section{Discussion of Results at OSN-1}

The geophysical log data in ODP Hole 843B show variations in both hole size and physical properties as a

Copyright 1992 by the American Geophysical Union.

Paper number 92GL00833

0094-8534/92/92GL-00833\$03.00 function of depth (Fig. 2). The borehole was drilled with a small diameter $(25 \mathrm{~cm})$ drillbit and is within 0.75 degrees of vertical, as indicated by a deviation log. The mechanical caliper $\log$ (Fig. 2, track 1) indicates that the hole is smaller than the bit size along some of its length, and in washouts, as large as the maximum caliper arm extension $(47 \mathrm{~cm})$. The enlargement of the hole at about $283 \mathrm{~m}$ depth below seafloor (bsf) occurs where the drilling penetration rate dropped from $10 \mathrm{~m} / \mathrm{h}$ to zero, probably indicating a rubble zone, and the hole had to be reamed to reach this depth again [Dziewonski, Wilkens, et al., 1992]. The calibration of the mechanical caliper may have been offset as the tool descended through remaining hole constrictions. An acoustic 4-arm caliper log, derived from digitally-processed borehole televiewer data [Barton, 1988] and calibrated to the bit size, shows the washouts to be as large as $66 \mathrm{~cm}$ and the typical hole size to measure 25 to $38 \mathrm{~cm}$ throughout most of the drilled section (Fig. 2, track 1).

The electrical resistivity of the crust, as measured by an induction $\log$, decreases from a value of somewhat more than $50 \Omega \mathrm{m}$ at $260 \mathrm{~m}$ bsf to less than $10 \Omega \mathrm{m}$ at $305 \mathrm{~m}$ bsf, accompanied by a systematic increase in gamma-ray activity (Fig. 2, tracks 2 and 3). Unfortunately, the gammaray sensor is too far above the bottom of the logging tool string to measure the deepest $20 \mathrm{~m}$ of the hole. The density $\log$ shows fairly consistent values of 2.7 to $2.85 \mathrm{~g} / \mathrm{cc}$ in the in-gauge, open-hole intervals, with large variations at fractures or in washout zones (see Broglia and Ellis [1990] for a discussion of the effects of hole size on density logs). The sharp decrease in density at about $244 \mathrm{~m}$ bsf is due to the contrast between the basalt and the sediment, which is revealed even though the rock had been cased off prior to logging. Compressional velocities from the sonic log (Fig. 2 , track 4 ) are between 4.8 and $5.2 \mathrm{~km} / \mathrm{s}$ in the basalt,

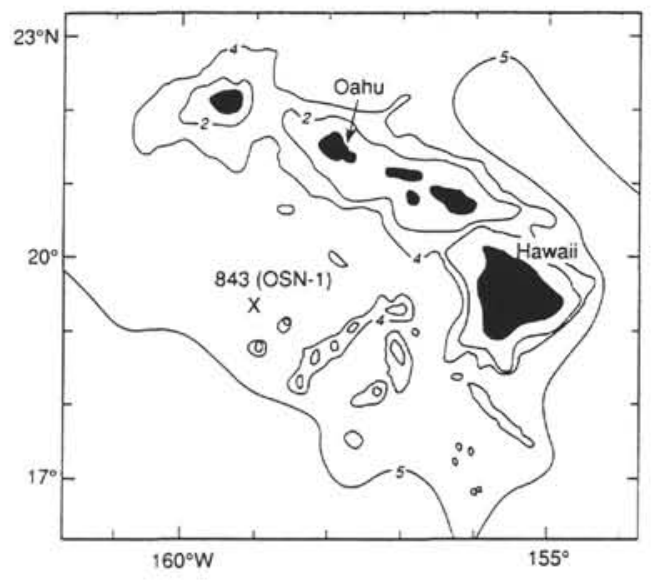

Fig. 1. Bathymetric location map of OSN-1 - ODP Hole 843B. 

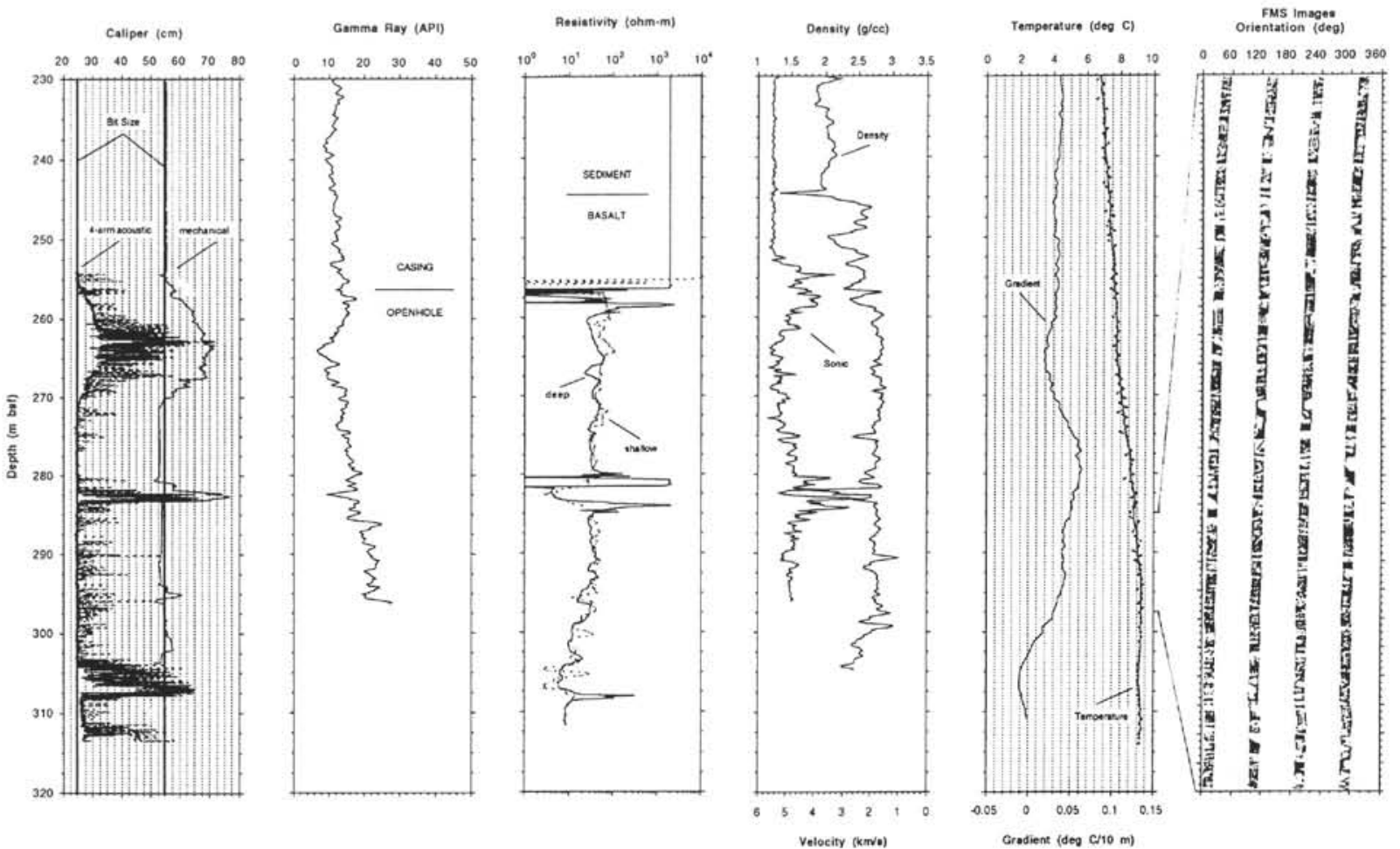

Fig. 2. Geophysical logs and core-based lithology in the basement section of Hole 843B: Track 1 - caliper logs: 4-arm (2-axis) acoustic (254-313 mbsf) and mechanical (230-307 mbsf). Note $30 \mathrm{~cm}$ offset for the mechanical caliper log. Track 2 - spectral gamma ray log (230-297 mbsf). Track 3 - deep and shallow resistivity logs (254-312 mbsf). Track 4 - density log (230-305 mbsf) and velocity log (230-297 mbsf). Track 5 - temperature and temperature gradient logs (230-312 mbsf). Track 6 - processed 4-pad FMS images (285-297.5 mbsf). Light banding indicates high resistivity; dark banding, high conductivity.

somewhat higher than the seismic measurements by Watts and ten Brink [1990], but in overall agreement with velocity measurements on core [Dziewonski, Wilkens, et al., 1992]. Unfortunately, shear-wave velocities could not be determined because sonic waveforms were not recorded. Velocity variations observed within the uppermost cased and cemented interval of basement probably do not reflect changes in physical properties of the formation. The relatively homogeneous properties from 270 to $280 \mathrm{~m}$ bsf and from 284 to $292 \mathrm{~m}$ bsf may distinguish two massive flows separated by a rubble zone from the more altered extrusives below, lithologies only partially $(17 \%)$ recovered by coring [Dziewonski, Wilkens, et al., 1992].

A borehole temperature log, run about 36 hrs after drilling was completed, and its gradient are also shown in Figure 2 (track 5). Because logging occurred before thermal equilibration was achieved, the decrease in temperature gradient observed below $290 \mathrm{~m}$ bsf possibly results from cool fluid that permeates the formation during drilling and subsequently flows back into the borehole. An equilibrium temperature profile in the hole is required to determine whether fluid flow will continue to depress the temperature gradient over time and to substantiate the existence of a permeable zone at depth. Wireline reentry experiments at this site, scheduled in late 1992, will record borehole temperatures for this purpose [F. Speiss, pers. comm.].

In order to obtain images of fractures that intersect the wellbore, borehole televiewer and formation microscanner (FMS) logs were recorded in Hole 843B. These logs have previously been demonstrated to show remarkable correlation with fracturing and fine-scale structure in crystalline rock [e.g., Paillet et al., 1990; Pezard and Luthi, 1990]. No high-angle features (fractures) were revealed in the digitally processed televiewer data in Hole 843B. In contrast, however, the FMS microresistivity images show evidence of pervasive fracturing, layered basalt pillows, and lava flows. In Figure 2 (track 6), the presence of dark (conductive) bands in an FMS image illustrate that sub-horizontal, electrically conductive features are present in this in-gauge section of the hole (from 285 to $297.5 \mathrm{~m} \mathrm{bsf}$ ). These lowresistivity features delineate contacts between basalt pillows and sheet lava flows that themselves are often fractured. The fact that these features are revealed in the electrical images and not in the televiewer data suggests that they are sealed by alteration, but with electrically conductive materials (e.g. clays).

\section{Comparison with other Oceanic Crustal Sites}

Similar suites of geophysical data have been obtained previously in both young and old oceanic crustal holes. Comparisons made between Site 843 and these sites, which have substantially greater penetration, enable us to speculate about the physical properties deeper in the section at this site and to compare the results here with those obtained in crust with a wide range of ages and ridge-axis types.

Hole 504B, drilled into 5.9 Ma crust in the eastern equatorial Pacific, penetrated an extrusive section composed of altered pillows and flows which is over $500 \mathrm{~m}$ thick [e.g. Honnorez, et al., 1985]. Electrical resistivities measured both near to and at substantial distance from the wellbore reveal a complicated, highly variable porosity, having 
interconnected voids on both a microscopic and a macroscopic scale [Anderson et al., 1985; Becker et al., 1985; Pezard, 1990]. Resistivity values vary from $<10 \Omega \mathrm{m}$ in basalt pillows, which comprise the bulk of the uppermost few hundred meters, to $>60 \Omega \mathrm{m}$ in individual massive flows. Velocity varies from 3.8 to $6.0 \mathrm{~km} / \mathrm{s}$ [Moos et al., 1990]. In general, Vp and resistivity are high in massive flows and low in basalt pillows, indicating that vertical gradients of these properties in extrusive basalts are more a function of basalt morphology than of depth of burial.

At another young crustal site drilled near the slowspreading mid-Atlantic Ridge (7.3 Ma), Hole 395A penetrated altered basalt pillows and occasional massive flows to more than $600 \mathrm{~m}$ bsf [Lawrence et al., 1983]. Variable physical properties gradients were also observed in log data from this hole, where basalt pillows have low $\mathrm{Vp}(<4 \mathrm{~km} / \mathrm{s})$ and low resistivity $(10-50 \Omega \mathrm{m})$ and massive flows have high $\mathrm{Vp}(>5 \mathrm{~km} / \mathrm{s})$ and high resistivity $(>200 \Omega \mathrm{m})$. In the deepest $150 \mathrm{~m}$ of this hole, the infilling of fractures observed in the core is accompanied by increases in $\mathrm{Vp}$, gamma-ray activity, and resistivity [Moos, 1990]. Bulk properties generally become more homogeneous with depth due to the infilling of fractures. Within each lithologic unit, increases in Vp and resistivity with depth are accompanied by decreases in gamma-ray activity, largely a consequence of the emplacement process moderated by subsequent alteration [Moos, 1990]. Temperature logs and hydrologic testing at Sites 395 and 504 reveal that in both cases fluid flow is constrained to intervals of high permeability in the shallow crust, primarily in basalt pillows [Becker et al., 1985; Morin et al., 1992]. Hydrothermal alteration in these young crustal sites, as indicated by both core and log data, gives evidence for the penetration of seawater in the crust to several hundred meters below the seafloor [e.g. Anderson et al., 1989].

At old crustal sites, physical properties continue to be controlled largely by extrusive morphology, and alteration processes occurring off the ridge axis continue to modify them over long time periods. In Hole $418 \mathrm{~A}$, for example, drilled in the northern Atlantic in 110 Ma crust through 50 $\mathrm{m}$ of massive basalt overlying basalt pillows [Donnelly, Francheteau, et al., 1979], massive flows (Vp $>5.5 \mathrm{~km} / \mathrm{s}, \mathrm{R}$

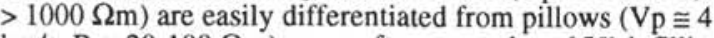
$\mathrm{km} / \mathrm{s}, \mathrm{R} \cong 20-100 \Omega \mathrm{m}$ ), even after as much as $15 \%$ infilling of the pillows by clays [Broglia and Moos, 1988]. In the southern central Indian Ocean, Hole 765D penetrated 277 $\mathrm{m}$ of massive flows and basalt pillows in $155 \mathrm{Ma}$ old crust and shows a correlation of high gamma-ray activity, low $\mathrm{Vp}$, and low resistivity in the logs with increased abundance of low-temperature alteration minerals in the core [Gradstein, Ladden, et al., 1990]. On the Broken Ridge, Hole 758A found pervasive alteration of thick lava flows and basalt pillows to $177 \mathrm{~m}$ depth in $80 \mathrm{Ma}$ old crust [Stow, Weissel, et al., 1989]. In the southern Pacific, Hole 597C penetrated mostly altered basalt flows to a depth of $70 \mathrm{~m}$, indicating seawater penetration to at least this depth into 54 Ma crust [Peterson et al., 1985]. In general, both logging and core data indicate variable physical property gradients within the upper few hundred meters of the crust, largely controlled by the distribution of massive and pillow basalts and alteration resulting from the accessibility of seawater through the extrusive section.

At Site 843, the observation that resistivity and Vp decrease and gamma-ray activity increases to $70 \mathrm{~m}$ bsf or deeper is not unusual. Based on comparisons of this site with those mentioned above, these variations are likely to be structurally controlled, possibly throughout the extrusive section of basalts. The velocity and resistivity measured at this $110 \mathrm{Ma}$ old site are intermediate between those measured at very young (e.g. Site 504) and at other old crustal (e.g. Site 418) sites. Hole 843B, similar in age to Hole
$418 \mathrm{~A}$, probably encountered basalt morphology that is characteristic of the uppermost oceanic crust, consisting of interbedded massive flows, altered extrusives, breccia and rubble. In comparison to young crustal sites, physical properties at Site 843 have undergone significant change by alteration, processes that these data suggest may be continuing off-axis for more than $100 \mathrm{Ma}$.

\section{Implications for Seismometer Placement}

The primary objectives of the OSN-1 pilot experiments are to assess the advantages of noise reduction with depth below the seafloor for seismic monitoring. Seismic noise may be reduced in boreholes due to (1) better coupling of the seismometer to the formation in high-density rock, and (2) better isolation from ocean currents by burial to several tens of meters [Purdy and Dziewonski, 1988; Harris et al., 1988; Hedlin and Orcutt, 1989]. In Hole 843B, long-term experiments are planned using a continuously-recording, 4 component seismometer (3-axis and pressure) emplaced in the open hole interval [Forsyth et al., 1991]. The instrument package should have minimal vertical tilt, maximum coupling to the borehole wall, and minimal disturbance by local hydrothermal effects.

The well log data at Site OSN-1 show that the hole meets the requirements of near-verticality and isolation from ocean currents and sediments, but does not penetrate unaltered oceanic crust, and sections are rough-walled. Although the much greater alteration in old oceanic crust (e.g. Hole 418A) in comparison to that at younger sites (e.g. Hole 395A) is associated with infilling of voids and hence more homogeneous, less permeable crust, the elastic properties at shallow depths are still significantly different from those at greater depths. For short-period seismic experiments (e.g. VSP's), the physical properties of layered rocks near a borehole geophone are critical in understanding the frequency response of the recorded signal [Hauge, 1981]. It is not clear how important these effects may be for longer period seismic waves (e.g. 10-100 s body and surface waves); therefore, analytical models should be used to deterimine the degree to which local velocity gradients and variable crustal structure affect the recorded signal. The Ocean Seismic Network may require only that seismometers be buried to depths of a few tens of meters in a near-vertical, smooth-walled borehole drilled into the seafloor.

The possibility of hydrothermal circulation, evidenced by a decrease in the geothermal gradient in Hole 843B, could also affect the thermal stability of any long-term instrument package emplaced near the bottom of this hole if it is not sealed with cement. The relatively homogeneous intervals from 270 to 280 and from 284 to $292 \mathrm{~m}$ bsf are therefore preferable to the bottom of the hole for wall-clamped geophones. As unaltered, hydraulically-isolated crust may not exist until substantially below the present bottom of Hole 843B, or at similar depths elsewhere, the technology and experimental design should be adequate to meet such ubiquitous crustal conditions.

\section{Conclusions}

Geophysical logs indicate considerable variability in the physical properties of the basement section at Site 843 . The analysis of these logs suggests that these crustal basalts are fractured and altered, a trend increasing with depth in the hole. Comparison of these results with those in other holes, which penetrate crust of less than 6 to more than 100 $\mathrm{Ma}$ and crust which originates at ridges having large variations in spreading rate, show that fracturing and alteration are common to substantial depth below the seafloor, and that physical properties are largely controlled by extrusive 
morphology, fracture permeability, and the accessibility of seawater. Given this understanding of the variability of physical properties in the shallow crust, critical for the recording and interpretation of seismic waves, the depth intervals from 270 to 280 and from 284 to $292 \mathrm{~m}$ bsf in Hole 843B are the most homogeneous of the hole and preferable to the bottom of the hole for emplacement of a borehole seismometer. Finally, the design of braodband seismic experiments at this or at other satisfactory OSN sites should take into consideration the results of downhole measurements and seismic modeling in order to determine whether an oceanic seismic observatory which provides high-quality data can be achieved in any stable borehole penetrating several tens of meters into the seafloor.

Acknowledgements. We greatly appreciate the assistance of the scientific party and crew of the JOIDES Resolution in the acquisition of these data. C. Broglia and R. Reynolds helped substantially in data processing. J. Tivy, R. Wilkens, and an anonymous reviewer contributed to the preparation of the manuscript. D. Goldberg was supported by NSF/JOI contract 66-84E. D. Moos was supported by ONR contract N00014-89-J-1316-P03. Lamont-Doherty Geological Observatory contribution no. 4917.

\section{References}

Anderson, R. N., J. C. Alt, and J. Malpas, 1989. Geochemical well logs and the determination of integrated chemical fluxes in Hole 504B, Eastern Equatorial Pacific, Proc. ODP Sci. Results, 111, 119-132.

Anderson, R.N., M.D. Zoback, S.H. Hickman, and R.L. Newmark, 1985. Permeability versus depth in the upper oceanic crust: in situ measurements in DSDP Hole 504B, eastern equatorial Pacific, Init. Reports DSDP, 83, 429-442.

Barton, C.A., 1988. Development of in-situ stress measurement techniques for deep drillholes, $\mathrm{PhD}$. Thesis, Stanford University, $192 \mathrm{pp}$.

Becker, K., Langseth, M.G., Von Herzen, R.P., Anderson, R.N. and Hobart, M.A., 1985. Deep crustal geothermal measurements, Hole 504B, Deep Sea Drilling Project Legs $69,70,83$, and 92., Init. Repts. DSDP, 83, 405418.

Broglia, C., and Ellis, D., 1990. The effect of alteration, formation absorption, and standoff on the response of the thermal neutron porosity log in gabbros and basalts: examples from DSDP-ODP Sites, J. Geophys. Res., 95(B6):9171-9188.

Broglia, C., and D. Moos, 1988. In-situ structure and properties of 110-Ma crust from geophysical logs in DSDP Hole 418A, Proc. ODP, Sci. Results, 102, 29-47.

Dziewonski, A. M., R. H. Wilkens, J. Firth, et al., 1992. Site 843 report, Proc. ODP, Init. Results, 136, College Station, TX.

Donnelly, T., J. Francheteau, W. Bryan, P. Robinson, M. Flower, M.H. Salisbury, et al., 1979. Site report, Init. Repts. DSDP, 51, 52, 53: Washington, DC.

Forsyth, D., S. Sacks, A. Trehu, et al., 1991. Proc. of a U.S. Pilot Experiment Task Force Meeting, $30 \mathrm{pp}$., Joint Oceanographic Inst., JOI/IRIS, Washington, DC.

Gradstein, F., J. Ladden, et al., 1990. Site report, Proc. ODP, Init. Results, 123, College Station, TX.
Harris, D., R. K. Cessaro, F. K. Dunnebier and D. A. Byrne, 1988. A permanent seismic station beneath the ocean bottom, Mar. Geophys. Res., 9, 67-94.

Hauge, P., 1981. Measurements of attenuation from vertical seismic profiles, Geophys., 46, 1548-1558.

Hedlin, M. S., and J. A. Orcutt, 1989. A comparative study of island, seafloor, and subseafloor ambient noise levels, Bull. Seismol. Soc. Am., 79, 172-179.

Honnorez, J., Laverne, C., Hubberton, H.-W., Emmermann, R., and Muehlenbachs, K., 1983. Alteration processes in Layer 2 basalts from Deep Sea Drilling Project Hole 504B, Costa Rica Rift, Init. Repts. DSDP, 69 , 509-546.

Lawrence, J.R., Drever, J.J., and Kastner, M., 1978. Low temperature alteration of basalts predominates at Site 395, Init. Repts. DSDP, 45, 609-612.

Mathews, M.A., J.H. Scott, and C.M. LaDelfe, 1985. Test pits for calibrating well logging equipment in fractured hardrock environment, Proc. Soc. Prof. Well Log Analysts $26^{h}$ Ann. Logging Sympos.

Morin, R.H., A.E. Hess, and K. Becker, 1992. In situ measurements of fluid flow in DSDP Holes 395A and 534A: Results from the DIANAUT program, Geophys. Res. Lett., 19(5), 509-512.

Moos, D., 1990. Petrophysical results from logging in DSDP Hole 395A, ODP Leg 109. Proc. ODP Sci. Results, 106/109, 237-253.

Moos, D., P. Pezard, and M. Lovell, 1990. Elastic properties of Oceanic Layer 2 from sonic full waveform logs in DSDP Holes 395A, 418A, and 504B, J. Geophys. Res., 95, 9189-9207.

Paillet, F., C. Barton, S. Luthi, F. Rambow, and J. Zemanek, 1990. Borehole imaging. Soc. Prof. Well Log Analysts, Houston, TX, $472 \mathrm{pp}$.

Peterson, C., R. Duncan, and K. F. Scheidegger, 1985. Sequence and longevity of basalt alteration at DSDP Site 597, Init. Repts. DSDP, 92, 505-515.

Pezard, P.A., 1990. Electrical properties of MORB, and implications for the structure of the oceanic crust in DSDP Hole 504B, J. Geophys. Res., 95, 9237-9264.

Pezard, P.A., and S. Luthi, 1990. Borehole electrical images in the basement of the Cajon Pass Scientific Drillhole, California: Fracture identification and tectonic implications, Geophys. Res. Lett., 15, 1017 1020.

Purdy, G. M., and A. Dziewonski, eds., 1988. Proc. of a Workshop on Broadband Downhole Seismometers in the Deep Ocean, 331 pp., Woods Hole Oceanographic Inst., JOI/USSAC, Washington, DC.

Stow, D., J. Weissel, et al., 1989. Site report, Proc. ODP, Init. Results, 116, College Station, TX.

Watts, A. B., and U. S. Ten Brink, 1989. Crustal structure, flexure and subsidence history of the Hawaiin Islands, J. Geophys. Res., 94, 10,473-10,500.

D. Goldberg, Lamont-Doherty Geological Observatory, Borehole Research Group, Rte. 9W, Palisades, N.Y. 10964

D. Moos, Stanford University, Dept. of Geophysics, Stanford, CA 94305

(Received February 4, 1992; revised April 7, 1992; accepted April 7, 1992) 